\title{
MODEL PENGEMBANGAN PERANGKAT PEMBELAJARAN SEJARAH BERORIENTASI METAKOGNITIF JENJANG SMA
}

\author{
Cahyo Budi Utomo \\ Jurusan Sejarah, Fakultas Ilmu Sosial, Universitas Negeri Semarang \\ cahyo211161@gmail.com
}

\begin{abstract}
The importance of metacognitive based history learning in the high school level as requested in the "curriculum 2013" is the main background of this research. The research is focused to find the model of development of metacognitive based learning through research and development (RED) type research. The results showed an essential component in achieving successful management of metacognitive based history learning in high school education which the curriculum as a core competency analysis and basic competencies, lesson plan development, and the development of assessment tools. Development model of metacognitive based learning at high school education have main characteristic of the inclusion of explicit metacognitive learning goals and assignments and devices equipped with a rubric and assessment questionnaire. Metacognitive based history learning instructional tools that are developed in senior high school level has been carried out as optimally as possible by involving history teachers in the process of development and testing through focus group discussions and questionnaire.
\end{abstract}

Keywords: Model, Instructional tool, Metacognitive, senior high school level

\begin{abstract}
ABSTRAK
Pentingnya orientasi metakognitif dalam perangkat pembelajaran sejarah jenjang SMA sebagaimana yang dikehendaki dalam implementasi kurikulum 2013 merupakan latar belakang utama penelitian ini. Penelitian difokuskan untuk menemukan model pengembangan perangkat pembelajaran berorientasi metakognitif melalui penelitian berjenis riset dan pengembangan (RED). Metode penelitian RED dilaksanakan melalui tiga tahap utama yaitu: tahap studi pendahuluan, tahap pengembangan, dan tahap uji publik. Hasil penelitian menunjukkan komponen esensial dalam mewujudkan keberhasilan pengelolaan pembelajaran sejarah berorientasi metakognitif pada jenjang pendidikan SMA adalah kurikulum sebagai bahan analisis kompetensi inti dan kompetensi dasar, pengembangan RPP, dan pengembangan perangkat assesmen. Model pengembangan perangkat pembelajaran sejarah berorientasi metakognitif pada jenjang pendidikan SMA yang dikembangkan memiliki ciri utama pada pencantuman tujuan pembelajaran metakognitif secara eksplisit dan dilengkapi dengan penugasan dan perangkat assesmen berupa rubrik dan angket. Pengembangan perangkat pembelajaran sejarah berorientasi metakognitif pada jenjang pendidikan SMA telah dilaksanakan seoptimal mungkin dengan melibatkan guru dalam proses pengembangan dan pengujian melalui FGD dan pengisian angket.
\end{abstract}

Kata Kunci: Model, Perangkat Pembelajaran, Metakognitif, Jenjang SMA

\section{PENDAHULUAN}

Dalam amanat UU Sikdiknas No 20 Tahun 2003 Bab X mengenai kurikulum pasal 36 ayat 1 yang berbunyi "Pengembangan kurikulum di lakukan dengan mengacu pada standar nasional pendidikan untuk mewujudkan tujuan pendidikan nasional." Kemudian dilanjutkan ayat 2, "Kurikulum pada semua jenjang dan jenis pendidikan dikembangkan dengan prinsip diver- 
ifkasi sesuai dengan satuan pendidikan, potensi daerah, dan peserta didik", dan ayat 3 berbunyi, "Kurikulum disusun dengan jenjang pendidikan dalam rangka Negara Kesatuan Republik Indonesia dengan memperhatikan peningkatan iman dan taqwa, peningkatan akhlak mulia, peningkatan potensi daerah dan lingkungan, tuntutan pembangunan daerah dan nasional, tuntutan dunia kerja, perkembangan ilmu pengetahuan, teknologi, seni, agama, dinamika perkembangan global dan persatuan nasional dan nilai-nilai keagamaan."

Menurut bahan uji publik kurikulum 2013 ada beberapa alasan antara lain tantangan masa depan semakin komplek untuk menghadapi tantangan global dan percepatan perkembangan teknologi informasi, kompetensi masa depan diperlukan kemampuan berkomunikasi secara kritis logis dan berkarakter agar mampu menghadapi dan menyelesaikan masalah global, persepsi masyarakat masih menitik beratkan aspek kognitif dalam hasil pembelajaran, dan berbagai fenomena negatif dikalangan pelajar antara lain tawuran, narkoba, pergaulan bebas, kecurangan.

Kurikulum 2013 merupakan pengembangan kurikulum sebelumnya (KTSP), keduanya mempunyai fungsi dan tujuan yang sama serta berpijak dari undang undang yang sama yaitu Undang Undang No.20 tahun 2003 Sistem Pendidikan Nasional. Pasal 3 undang undang tersebut menyatakan bahwa fungsi Pendidikan Nasional adalah mengembangkan kemampuan dan membentuk watak serta peradaban bangsa yang bermartabat dalam rangka mencerdaskan kehidupan bangsa. Sedangkan tujuan pendidikan nasional yang ingin dicapai adalah untuk berkembangnya potensi peserta didik agar menjadi manusia yang beriman dan bertakwa kepada Tuhan Yang Maha Esa, berakhlak mulia, sehat, berilmu, cakap, kreatif, mandiri, dan menjadi warga negara yang demokratis serta bertanggung jawab.

Dari hasil evaluasi beberapa hal yang dikoreksi dan direvisi pada KTSP yang akan menjadi titik tekan dalam kurikulum 2013 antara lain, pertama, konten KTSP masih terlalu padat (mata pelajaran banyak, materinya meluas, dan tingkat kesukarannya melampaui usia anak); Kedua, belum sepenuhnya berbasis kompetensi, belum menggambarkan secara holistik domain sikap, keterampilan, dan pengetahuan; Ketiga, belum terakomodasi pendidikan karakter, metodologi pembelajaran aktif, keseimbangan soft skills dan hard skills, dan kewirausahaan; Keempat, belum peka dan tanggap terhadap perubahan sosial yang terjadi pada tingkat lokal, nasional, maupun global; Kelima, standar proses pembelajaran belum menggambarkan urutan pembelajaran yang rinci sehingga membuka peluang penafsiran yang beraneka ragam dan berujung pada pembelajaran yang berpusat pada guru; Keenam, standar penilaian belum mengarahkan pada penilaian berbasis kompetensi (sikap, keterampilan, dan pengetahuan) dan belum tegas menuntut adanya remediasi secara berkala.

Hasil evaluasi di atas tidak serta merta menjustifikasi kurikulum sebelumnya lebih jelek dan harus ditinggalkan sama sekali, karena pada dasarnya kurikulum 2013 adalah koreksi dan penyempurnaan kurikulum sebelumnya. Sebaik apapun kurikulum jika tidak ditunjang dengan guru yang profesional tidak akan memberikan dampak yang lebih baik.

Peran guru sebagai ujung tombak dalam implementasi kurikulum 2013, mengundang banyak pertanyaan dan berusaha mencari jawaban sekaligus langkah langkah persiapan beradaptasi dengan kurikulum baru. Terbayang 
pekerjaan berat di depan mata untuk mempersiapkan perangkat pembelajaran yang meliputi analisis kompetensi dan RPP kurikulum 2013, padahal sewaktu KTSP diberlakukan hingga saat ini belum bisa diimplementasikan dengan optimal dalam pembelajaran. Guru dituntut sebagai pembelajar cepat untuk meramu empat komponen kurikulum 2013 yang meliputi standar isi, standar proses, standar penilaian, dan standar kompetensi lulusan. Hasil yang diharapkan adalah peningkatan kompetensi siswa yang seimbang antara sikap (attitude), ketrampilan (skill), dan pengetahuan (knowledge) untuk menghasilkan lulusan yang produktif, kreatif, inovatif yang mampu menjawab tantangan global.

Penyiapan dan pembinaan guru dalam kurikulum 2013 menjadi salah satu faktor keberhasilan implementasinya disamping faktor lain seperti, penguatan peran pemerintah, ketersediaan buku, dan penguatan manajemen dan budaya sekolah. Untuk membuat siswa yang kreatif dan inovatif diperlukan guru yang lebih kreatif dan inovatif dalam menyiapkan materi, penilaian, dan metoda penyampaian yang menyenangkan dengan memperhatikan kesiapan psikologi siswa sebelum belajar. Perubahan perubahan yang ada harus segera disikapi agar ketika kurikulum 2013 diberlakukan guru sudah siap mental untuk menerapkan dalam pembelajaran.

Guru merupakan komponen kunci yang dituntut mampu memenuhi tuntutan sebagai pembelajar cepat untuk meramu empat komponen kurikulum 2013 yang meliputi standar isi, standar proses, standar penilaian, dan standar kompetensi lulusan. Disisi lain, manajemen pembelajaran di kelas yang berhasil merupakan prasyarat bagi keberhasilan proses pembelajaran secara keseluruhan, oleh sebab itu, manajemen pembelajaran di kelas harus dikuasai oleh guru secara baik.

Sesuai dengan rancangan kurikulum 2013 pada jenjang SMA, ruang lingkup Standar Kompentensi Lulusan (SKL) pada domain pengetahuan adalah: memiliki pengetahuan faktual, konseptual, prosedural dan metakognitif dalam ilmu pengetahuan, teknologi, seni, dan budaya dengan wawasan kemanusiaan, kebangsaan, kenegaraan, dan peradaban terkait penyebab fenomena dan kejadian.

Kata kunci metakognitif dalam domain pengetahuan memiliki konsekuensi logis bagi guru untuk mampu mengintegrasikannya secara eksplisit dalam perencanaan pelaksanaan, proses pembelajaran di kelas secara optimal, dan penilaian yang komprehensif, sehingga keseimbangan implementasi domain pengetahuan faktual, konseptual, prosedural dan metakognitif di kelas merupakan indikator keberhasilan guru dalam mengelola pembelajaran. Penelitian ini dirancang untuk menghasilkan model pengembangan perangkat pembelajaran sejarah berorientasi metakognitif pada jenjang SMA.

\section{METODE PENELITIAN}

Penelitian dirancang sebagai penelitian Riset and Development (R\&D) mengacu, memadukan, dan memodifikasi model Plomp (1997), Borg and Gall (1983), Tiagarajan (1974), dan Sugiyono (2010) yang diadaptasi dan dipadukan dengan memodifikasi. Langkah-langkah pengembangan model dikelompokkan menjadi tiga langkah utama yaitu: studi pendahuluan, tahap pengembangan, dan tahap uji publik.

Kegiatan pada tahapan studi pendahuluan meliputi studi literatur studi/ pengumpulan data lapangan berkaitan dengan permasalahan yang akan 


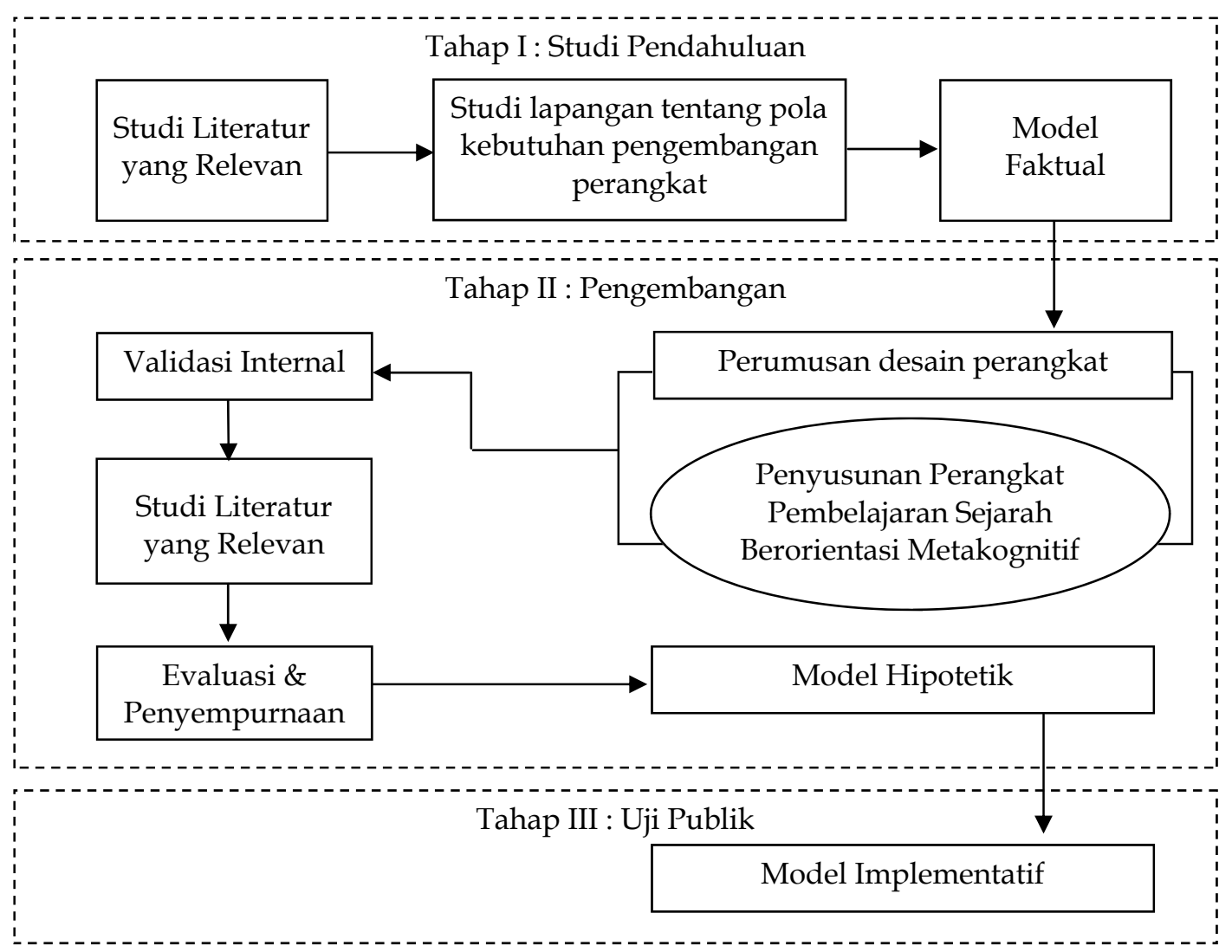

Gambar 1. Tahapan Penelitian dan Pengembangan

dipecahkan, mendeskripsikan, dan menganalisis temuan lapangan. Hasil pemotretan kondisi faktual ini menjadi bahan dasar untuk merancang desain model awal atau model faktual dari perangkat pembelajaran sejarah berorientasi metakognitif.

Pada tahap pengembangan, kegiatannya meliputi merumuskan rencana pengembangan model perangkat pembelajaran sejarah berorientasi metakognitif; menetapkan tujuan yang akan dicapai pada setiap tahapan pengembangan, dan melakukan diskusi terfokus dengan teman sejawat, ahli, dan praktisi, merencanakan studi kelayakan secara terbatas; mengembangkan produk awal yang akan dikembangkan; validasi internal dengan sejawat, ahli dan praktisi. Tujuan utama langkah ini adalah untuk mengetahui kecocokan desain perangkat pembelajaran sejarah berorientasi metakognitif terhadap pencapaian tujuan penelitian. Berdasarkan hasil validasi internal melalui diskusi terfokus dengan teman sejawat, pakar, dan praktisi tersebut dilakukan perbaikan/penyempurnaan, sehingga desain perangkat yang dikembangkan sudah merupakan model hipotetik.

Tahap Uji Publik meliputi kegiatan melakukan pengujian hasil pengembangan (model hipotetik) melalui focus group discussion yang diperluas dengan pesert para calon pengguna dan melakukan perbaikan dalam rangka finalisasi produk akhir. Tujuan utama dalam langkah ini menyimpulkan apakah model yang dikembangkan sesuai atau belum sebagai model yang diinginkan oleh para pengguna di 
Model Pengembangan Perangkat ... - Cahyo Budi Utomo

lapangan. Selanjutnya model yang diinginkan berupa perangkat pembelajaran sejarah berorientasi metakognitif dapat segera diimplementasikan oleh para pengguna di kelas. Pada tahap ini kegiatannya termasuk melakukan perbaikan akhir terhadap model yang dikembangkan berdasarkan hasil uji publik, sehingga model hipotetik setelah melalui uji publik direvisi menjadi model implementatif atau model yang siap diimplementasikan.

Analisis data dalam penelitian ini menggunakan analisis deskriptif sederhana sesuai dengan jenis data yang diperoleh di setiap tahapan penelitian. Analisis data deskriptif sangat tepat, mengingat data-data yang terkumpul merupakan data-data deskriptif sebagai hasil dari tanggapan, koreksi, masukan, diskusi dari berbagai sumber data pada setiap tahapan pengembangan model perangkat pembelajaran sejarah berorientasi metakognisi.

\section{HASIL DAN PEMBAHASAN}

\section{Hasil Penelitian}

Mengacu pada rancangan penelitian yang telah ditetapkan, penelitian Riset and Development (R\&D) ini mengacu pada adaptasi berbagai model penelitian pengembangan dari beberapa pakar (Plomp, 1997: Borg and Gall, 1983; Tiagarajan, 1974; dan Sugiyono, 2010). Menjadi penelitian tiga tahap, yaitu: tahap pendahuluan, tahap pengembangan, dan tahap uji publik.

Dalam penelitian ini, fokus pengembangan model perangkat pembelajaran berorientasi metakognitif diarahkan pada mata pelajaran IPS-Sejarah yang dikembangkan lebih lanjut perangkat pembelajarannya dalam penelitian ini sebagai model implementatif.

\section{$\underline{\text { Studi Pendahuluan }}$}

Studi pendahuluan yang telah dilakukan dengan melakukan kegiatan orientasi dan observasi penerapan kurikulum terkini pada jenjang SMA memberikan informasi bahwa saat ini pada jenjang SMA kurikulum yang diterapkan ada yang masih KTSP 2006, dan ada yang sudah mulai mengimplementasikan kurikulum 2013.

Proses pembelajaran dalam kurikulum 2013 ditopang oleh pendekatan saintifik dan kontekstual dimana diharapkan kemampuan kreatifitas dapat diperoleh melalui: observing (mengamati), questioning (menanya), associating (menalar), experimenting (mencoba), dan networking (membentuk jaringan/berkomunikasi). Proses pembelajaran dalam kurikulum 2013 didukung proses penilaian yang berbasis autentic assesment seperti penilaian portofolio, penilaiamn projek, dan penilaian kinerja.

Sesuai dengan tujuan penelitian ini, studi pendahuluan lainnya dalam penelitian ini diarahkan untuk mendapatkan dasar teori dan konsepkonsep terkait aspek metakognitif yang dapat disinergikan dengan kebutuhan pengembangan perangkat pembelajaran sesuai kurikulum 2013. Hasil studi pendahuluan terkait hal ini menunjukkan terdapat empat tahapan kunci/utama dalam menerapkan skill metakognitif dalam pembelajaran (Erskine, 2009).

Empat tahapan kunci metakognitif yang efektif untuk memunculkan skill metakognitif selanjutnya disebut Metacognitive Skill Instruction (MSI) yang didesain untuk membantu siswa belajar dan menggunakan empat komponen metakognitif yang diidentifikasi oleh Hartman (2001), McCormick (2006), dan Schraw dan Dennison (1984), bahwa siswa akan dapat: (1) Identify: melakukan identifikasi atas tugas yang 
Paramita Vol. 25, No. 1 - Januari 2015

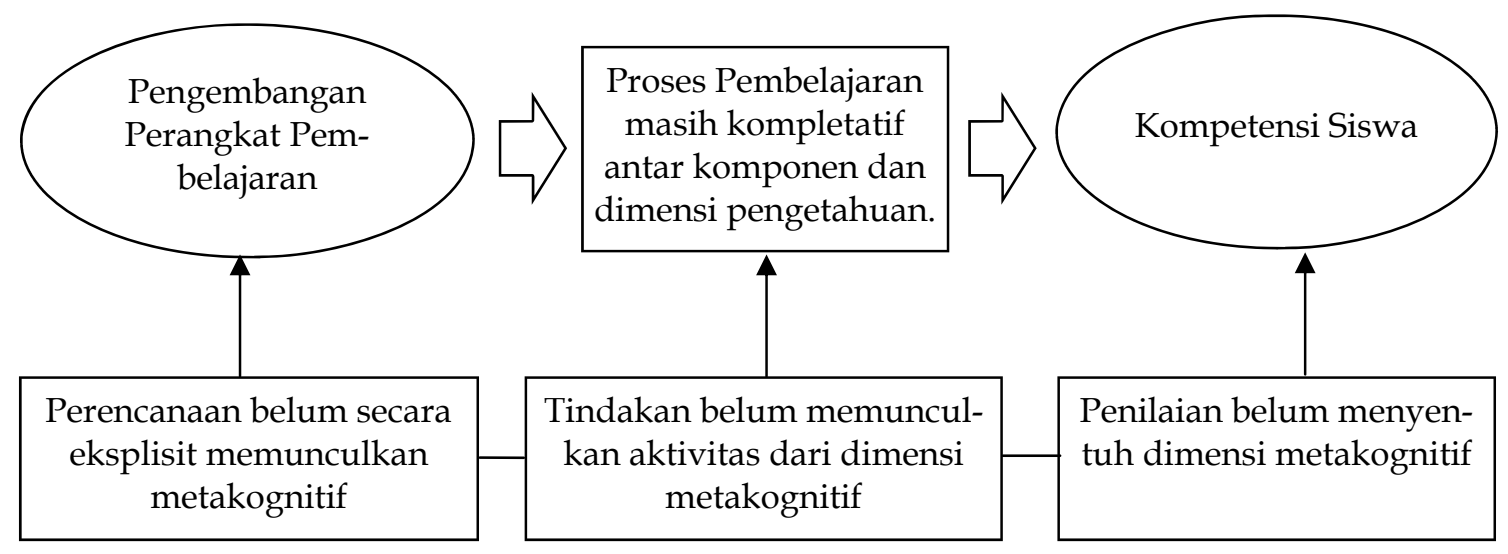

Gambar 2 Model Faktual Pengembangan Perangkat Pembelajaran Metakognitif

diberikan oleh guru, (2) Determine: menentukan pendekatan awal dalam mengerjakan tugas guru, (3) Monitoring: melakukan monitoring terhadap kegiatan pembelajaran menggunakan skill manajemen informasi dan teknik yang komprehensif, dan (4) Evaluate: mengevaluasi hasil pekerjaan/ penugasan secara mandiri sekaligus menilai efektifitas dan efisiensi dari tindakan yang dipilih dalam menyelesaikan penugasan.

Studi pendahuluan berikutnya adalah menyiapkan tabel bantu dalam penyusunan sketsa pembelajaran untuk mempermudah penempatan tujuan dan aktivitas pembelajaran dalam taksonomi pembelajaran. Untuk tujuan ini, kerangka landasan untuk pembelajaran, pengajaran, dan assesmen, mengadaptasi yang dikembangkan Anderson \& Krathwohl (2010). Analisis sketsa pembelajaran dituangkan dalam tabel dua dimensi yang mengkorelasikan empat dimensi pengetahuan yaitu: pengetahuan faktual, pengetahuan konseptual, pengetahuan prosedural dan pengetahuan metakognitif, dengan enam dimensi proses kognitif yaitu: mengingat, memahami, mengaplikasikan, menganalisis, mengevaluasi, dan mencipta.

Hasil studi pendahuluan menghasilkan potret tentang pengem- bangan perangkat pembelajaran sejarah oleh guru yang belum mencerminkan adanya dimensi pengetahuan metakognitif. Hal ini bisa dilihat dari rencana pelaksanaan pembelajaran yang belum secara eksplisit menuangkan dimensi pengetahuan metakognitif. Demikian pula dalam proses pembelajaran dan perangkat penilaiannya. Hasil pemotretan pada studi pendahuluan menghasilkan model faktual yang dapat ditunjukkan pada Gambar 2.

Pada Gambar 2, model faktual pengembangan perangkat pembelajaran metakognitif di atas, secara ringkas menggambarkan hasil pemotretan pengembangan pembelajaran berdimensi metakognitif yang terjadi dilapangan. Berdasarkan hasil pemotretan tersebut, diketahui bahwa model faktual masih lemah dalam penerapan prinsip-prinsip pembelajaran metakognitif. Dalam pengembangan pembelajaran, belum terlihat penyusunan RPP yang mencerminkan secara eksplisit tentang dimensi pengetahuan metakognitif, dan pengorganisasian guru dalam pengembangan perangkat pembelajaran juga masih bersifat umum. Dalam pembelajaran metakognitif, yang di dalamnya terdapat level atau tahapan metakognitif belum disajikan atau jikapun ada sajiannya masih bersifat kompletatif (terpisah dengan komponen RPP). 


\section{Tahap Pengembangan}

Berdasarkan hasil kajian pada studi pendahuluan yang menghasilkan model faktual, dalam tahap pengembangan peneliti menggunakan hasilhasil studi pendahuluan tersebut untuk merancang model perangkat pembelajaran sejarah berbasis metakognitif bagi siswa SMA sesuai dengan kurikulum 2013. Langkah awal pengembangan memanfaatkan seluruh hasil studi pendahuluan dan analisis terhadap kurikulum 2013 menghasilkan model hipotetik disertai dengan pengembangan draf perangkat pembelajaran berupa: (1) Analisis kompetensi, (2) Rencana Pelaksanaan Pembelajaran (RPP), dan (3) Assessment.

Hasil perbaikan dari model faktual, setelah melalui perancangan oleh peneliti dan dilakukan validasi internal dan diperbaiki menghasilkan model hipotetik seperti terlihat pada gambar 3, sedangkan bahan penyerta model berupa draf AK (Analisis Kompetensi), RPP (Rencana Pelaksanaan Pembelajaran), dan Instrumen Assessment.

Draf RPP dan instrumen penilaian beserta rubriknya, kemudian divalidasi secara internal oleh teman sejawat, ahli dan praktisi melalui kegiatan Focus Group Discussion (FGD) terbatas.
Kegiatan FGD terbatas melibatkan sejawat, ahli dan guru kelas yang sesuai. Gambaran rancangan awal model dan paparan draft perangkatnya berupa RPP disampaikan kepada guru selaku praktisi untuk memberikan gambaran dan penjelasan yang lebih rinci kepada guru mengenai aspek-aspek metakognitif yang diharapkan muncul dalam kegiatan pembelajaran sejarah di kelas. Muatan metakognitif dalam RPP dikomunikasikan untuk mendapatkan respon dan tanggapan dari guru-guru sejarah sehingga diperoleh gambaran model hipotetik di dalam kelas apabila perangkat pembelajaran ini diterapkan.

Masukan dan kritik dari sejawat, praktisi, dan pakar kemudian didiskusikan bersama untuk menyempurnakan draft perangkat pembelajaran yang dipaparkan oleh peneliti. Simpulan dari kegiatan review digunakan oleh peneliti untuk melakukan evaluasi dan revisi lebih mendalam terhadap draf perangkat pembelajaran yang dikembangkan. Tanggapan dan rekomendasi dari ahli dan praktisi juga menjadi pertimbangan penting dalam proses revisi model perangkat pembelajaran seajarah dan panduan. Hasil dari proses ini selanjutnya dilakukan pengujian publik.

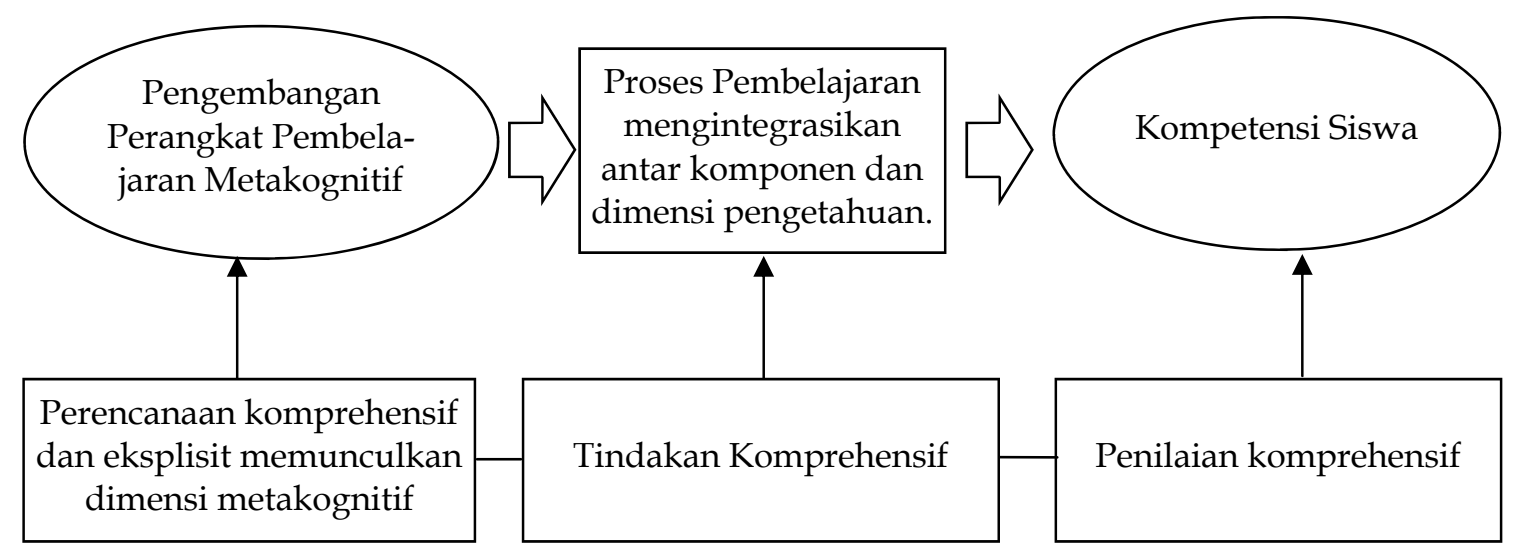

Gambar 3 Model Hipotetik Pengembangan Perangkat Pembelajaran Metakognitif 


\section{Tahap Uji Publik}

Tahap ini dilakukan dengan mengundang para guru dan bersamasama melakukan Focus Group Discusion (FGD) yang diperluas, untuk mematangkan model perangkat pembelajaran berorientasi metakognitif yang telah dikembangkan beserta panduan pengembangan perangkatnya dan telah direview oleh sejawat, pakar dan praktisi secara terbatas. Hasil dari uji publik ini memunculkan penyesuaianpenyesuaian menurut para guru di lapangan. Hasil revisi melahirkan model implementatif, yaitu model final yang siap didesiminasikan oleh para guru peserta FGD berdasarkan kesepakatan bersama. Model dan perangkat pembelajaran terlampir.

\section{Hasil FGD pengembangan perangkat pembelajaran berorientasi metakogni- tif}

Mencermati model perangkat pembelajaran berorientasi metakognitif yang telah dikembangkan oleh peneliti, para guru dikumpulkan dalam sebuah kegiatan FGD. Kegiatan dirancang peneliti untuk mendapatkan masukan dan perbaikan terhadap perangkat yang telah dikembangkan. Berikut ini adalah beberapa masukan dan tanggapan para guru. Pertama, model perangkat pembelajaran yang dikembangkan oleh peneliti berupa analisis kompetensi, rencana pelaksanaan pembelajaran (RPP) dan assesmen dinilai lengkap. Kedua, guru berpendapatan tujuan pembelajaran metakognitif dalam RPP masih terlalu umum, sehingga perlu dipertegas dengan menyebutkan aktivitas dan target bahasan yang diinginkan. Ketiga, perlu dijelaskan lebih lengkap pada komponen assesmen terkait kinerja/pencapaian metakognitif. Keempat, tidak semua pokok bahasan dapat dikembangkan melalui kegiatan pembelajaran berorientasi metakognitif namun demikian, orientasi metakognitif cukup penting untuk dilaksanakan melalui berbagai upaya kreatif yang dikembangkan guru. Kelima, Guru berpendapat bahwa kondisi sekolah (sarana prasarana), latar belakang akademik siswa, dan lingkungan belajar dan faktor-faktor lain yang berpengaruh terhadap pelaksanaan pembelajaran perlu dipertimbangkan sebelum melaksanakan kegiatan pembelajaran dengan model perangkat RPP yang diajukan oleh peneliti.

Beberapa pendapat guru dalam kegiatan FGD yang dirangkum oleh peneliti merupakan bahan masukan penting dalam pengembangan model perangkat pembelajaran. Terkait dengan hal tersebut, peneliti juga mencatat beberapa hal yang perlu diluruskan dalam upaya penerapan model yang telah dikembangkan ini secara optimal di kelas dan mampu menjadi inspirasi bagi guru dimasa yang akan datang untuk mengembangkan model sejenis secara mandiri. Pendapat peneliti dalam kegiatan ini adalah: Pertama, model perangkat pembelajaran berorientasi metakognitif yang dikembangkan merupakan perangkat pembelajaran yang mengacu pada kurikulum 2013 dimana saat ini implementasinya masih dalam tahap awal sehingga guru masih terus berupaya meningkatkan pemahamannya.

Kedua, ada indikasi guru menganggap kurikulum 2013 adalah kurikulum baru yang tidak ada kaitannya dengan kurikulum sebelumnya sehingga pemahaman guru mengenai hal ini perlu diperbaiki.

Ketiga, kebutuhan integrasi metakognitif dalam pembelajaran siswa jenjang SMA merupakan amanah Undang-Undang yang wajib diketahui oleh 
guru sejak dini, sehingga kesadaran akan pentingnya metakognitif mutlak dibutuhkan oleh guru dalam merancang pembelajaran di kelas.

Keempat, peneliti mengusulkan sebuah model perangkat pembelajaran berorientasi metakognitif dalam rangka memenuhi amanah Undang-Undang yang perlu diketahui oleh guru.

Kelima, model perangkat pembelajaran berorientasi metakognitif yang diusulkan telah dilengkapi rubrik metakognitif untuk guru dan siswa termasuk rubrik refleksi metakognitif yang penting dalam assesmen dimensi metakognitif siswa.

\section{Pembahasan Model Pengembagan Perangkat Pembelajaran Sejarah Berorientasi Metakognitif}

Hasil pengembangan perangkat pembelajaran sejarah berorientasi metakognitif yang diperoleh dalam penelitian telah dilakukan uji publik melalui kegiatan FGD yang diikuti oleh para guru sejarah SMA di Kendal. Draf perangkat pembelajaran berupa analisis kompetensi dan RPP dicermati oleh guru peserta FGD untuk selanjutnya diberi masukan sesuai dengan kapasitas guru mata pelajaran yang bersangkutan. Melalui kegiatan FGD dalam rangka uji publik terbatas perangkat pembelajaran sejarah berorientasi metakognitif untuk SMA, peneliti mengawali dengan memaparkan karakteristik kurikulum 2013 yang secara eksplisit menyebutkan pengetahuan metakognitif merupakan salah satu dimensi yang harus dicapai dalam pembelajaran sejarah siswa jenjang SMA disamping pengetahuan faktual, pengetahuan konseptual, dan pengetahuan prosedural.

Pelaksanaan orientasi metakognitif diawali oleh guru pada saat mengembangkan RPP berdasarkan analisis kom- petensi yang telah disusun sebelumnya. Dalam tahap ini guru dapat menggunakan guide yang diusulkan dalam penelitian ini yang berpedoman pada empat tahapan kunci metakognitif yang efektif dalam rangka memunculkan skill metakognitif selanjutnya disebut Metacognitive Skill Instruction (MSI) yang didesain untuk membantu siswa belajar dan menggunakan empat komponen metakognitif yang diidentifikasi oleh Hartman (2001), McCormick (2006), dan Schraw dan Dennison (1984).

Selain MSI, guru juga perlu mengadopsi pendekatan saintifik dan kontekstual dimana diharapkan kemampuan kreatifitas siswa terbentuk melalui pendekatan ini. Dalam praktiknya, pengembangan perangkat pembelajaran sejarah berorientasi metakognitif memiliki karakteristik yang berbeda-beda dalam implementasinya tergantung pada, pokok materi yang sedang dibahas dan ketersediaan sarana dan prasarana pembelajaran. Guru memiliki otoritas penuh untuk mendesain perangkat pembelajaran yang sesuai dengan kebutuhan masingmasing kelas.

Dalam penelitian ini diberikan contoh hasil-hasil pengembangan perangkat pembelajaran sejarah berorientasi metakognitif untuk jenjang SMA yang telah dilakukan pengujian. Perangkat yang dihasilkan dapat diadaptasi, dimodifikasi, dan disempurnakan lebih lanjut oleh para guru sejarah sesuai dengan karakteristik kelas yang dituju.

\section{SIMPULAN}

Komponen esensial dalam mewujudkan keberhasilan pengelolaan pembelajaran sejarah berorientasi metakognitif pada jenjang pendidikan SMA adalah kurikulum sebagai bahan 
analisis kompetensi inti dan kompetensi dasar, pengembangan RPP, dan pengembangan perangkat assesmen. Model pengembangan perangkat pembelajaran sejarah berorientasi metakognitif pada jenjang pendidikan SMA di Kendal telah berhasil dikembangkan dengan ciri utama pada pencantuman tujuan pembelajaran metakognitif secara eksplisit dalam RPP dan dilengkapi dengan penugasan dan perangkat assessment berupa rubrik dan angket sebagai bagian tak terpisahkan dari RPP. Pengembangan perangkat pembelajaran sejarah berorientasi metakognitif pada jenjang pendidikan SMA di Kendal telah dilaksanakan seoptimal mungkin dengan melibatkan guru dalam proses pengembangan dan pengujian melalui FGD dan pengisian angket, sehingga menghasilkan model implementatif yang siap diimplementasikan oleh para guru dalam pembelajaran sejarah.

\section{DAFTAR PUSTAKA}

Anderson, L.W, \& Krathwol, D.R. (ed.). 2001. A Taxonomy for Learning Teaching and Assessing. A Revision of Bloom's Taxonomy of Educational Objectives.New York: Addison Wesley Longman, Inc.

Erskine, D.L., 2009. "Effect of Prompted Reflection and Metacognitive Skill Instruction on University Freshmen's use of Metacognition". Ph.D. Thesis. Department of Instructional Psychology and Technology, Brigham Young
University.

Gall, MD, Gall, JP and Borg, WR. 1983. Educational Research: An Introduction. New York: Pearson Education, Inc.

Hartman, H. J. 2001. "Developing students' metacognitive knowledge and skills". dalam H. J. Hartman (Ed.). Metacognition in Learning and Instruction: Theory, Research and Practice. Boston: Kluwer. Hlm. $33-63$.

2001. "Teaching Metacognitively". dalam H. J. Hartman (Ed.), Metacognition in Learning and Instruction: Theory, Research and Practice. Boston: Kluwer. Hlm. 149 - 172.

McCormick, C. B. 2006. "Metacognition and learning". Dalam P. A. Alexander, \& P. H. Winne (Ed). Handbook of Educational Psychology. Edisi 2. Mahwah, New Jersey: Lawrence Erlbaum. Hlm. 79-102.

Peraturan Menteri Pendidikan Nasional No. Nomor 22 tahun 2006 tentang Standar Isi untuk Satuan Pendidikan Dasar dan Menengah.

Plomp, Tjeerd. 1997. An Introduction to Educational Design Research. Proceedigs of the Seminar Conducted. The East China Normal University.

Schraw, G., \& Dennison, R. S. 1994. Assessing metacognitive awareness. Contemporary Educational Psychology, 19, 460-475.

Sugiyono. 2012. Metode Penelitian Kuantitatif, Kualitatif, dan $R \mathcal{E} D$. Bandung: ALFABETA

Thiagarajan, Sivasailam, Ect. 1974. Instructional Development for Training Teachers of Exceptional Children. BloomingtonIndiana: Indiana University.

Undang-Undang Nomor 20 tahun 2003 tentang Sistem Pendidikan Nasional. 